\title{
KDM2B Gene Mutation
}

National Cancer Institute

\section{Source}

National Cancer Institute. KDM2B Gene Mutation. NCI Thesaurus. Code C153247.

A change in the nucleotide sequence of the KDM2B gene. 